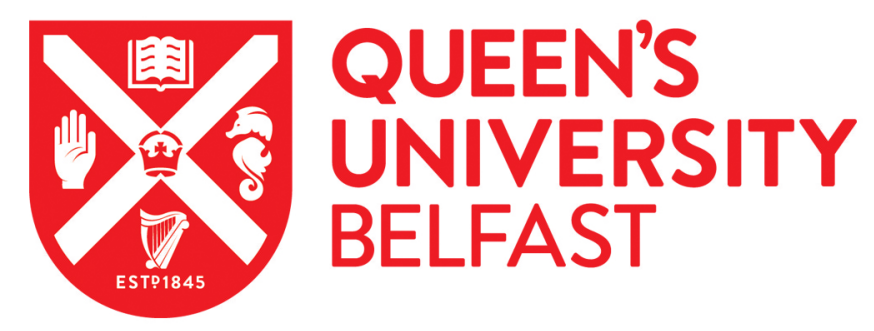

\title{
Does culture matter in ABA-based autism interventions? Parent and professional experiences in the UK and China
}

Liao, Y., Dillenburger, K., \& Buchanan, I. (2017). Does culture matter in ABA-based autism interventions? Parent and professional experiences in the UK and China. European Journal of Behavior Analysis.

https://doi.org/10.1080/15021149.2017.1399657

\section{Published in:}

European Journal of Behavior Analysis

\section{Document Version:}

Peer reviewed version

Queen's University Belfast - Research Portal:

Link to publication record in Queen's University Belfast Research Portal

\section{Publisher rights}

(c) 2017 Norwegian Association for Behavior Analysis. This work is made available online in accordance with the publisher's policies. Please refer to any applicable terms of use of the publisher.

\section{General rights}

Copyright for the publications made accessible via the Queen's University Belfast Research Portal is retained by the author(s) and / or other copyright owners and it is a condition of accessing these publications that users recognise and abide by the legal requirements associated with these rights.

Take down policy

The Research Portal is Queen's institutional repository that provides access to Queen's research output. Every effort has been made to ensure that content in the Research Portal does not infringe any person's rights, or applicable UK laws. If you discover content in the Research Portal that you believe breaches copyright or violates any law, please contact openaccess@qub.ac.uk. 


\section{Does Culture matter in ABA-based Autism Interventions?}

Parent and Professional Experiences in the UK and China

\section{European Journal of Behaviour Analysis (2017)}

https://www.tandfonline.com/doi/abs/10.1080/15021149.2017.1399657?journalCode=rej

o20

Yini Liao*, Karola Dillenburger*, and Ian Buchanan**

*Centre for Behaviour Analysis, School of Education, Queen's University Belfast

**Department of Social Policy \& Social work, University of York 


\begin{abstract}
The present study compared cultural differences in the UK and China in relation to Applied Behaviour Analysis (ABA)-based interventions for children with autism. In the UK, seven participants were interviewed (five professionals and two parents of children with autism). In China, eight participants took part in interviews (five professionals and three parents). Marked cultural and policy differences were found in the delivery of ABA-based early interventions for children with autism in the UK and China, e.g., home vs school programmes. The delivery of effective intervention programmes should accommodate issues arising from different cultural backgrounds is necessary for.
\end{abstract}

Key words: Autism, behaviour intervention, comparative study 
This study explores the influence of contrasting cultural, medical/care and social contexts in the UK and China on the application of Applied Behaviour Analysis-based (ABA) interventions for children diagnosed with Autism Spectrum Disorder (ASD). The main purpose is to encourage parents and professionals in the UK and China to share their experiences and foster a climate in which further research can take place.

\section{Autism: Definition and Prevalence}

The term 'autism' was first used by Asperger (1944; translated by Frith, 1991) and Kanner (1943). It was officially included as a diagnostic category in 1980 by the Third Edition of the Diagnostic and Statistical Manual (DSM-3; APA, 1980). In mainland China, autism was first reported in 1982 (Tao, 1987) and included as a diagnostic category in the second edition of the Chinese Category of Mental Disease (CCMD-2) in 1995 (Clark \& Zhou, 2005). People diagnosed with autism show long-term difficulties in social communication and social interaction, alongside ritualized/repetitive behaviour (APA, 2013).

Estimations of prevalence of Autism Spectrum Disorder (ASD) in the English-speaking world vary between 1-2\% (DHSSPS, 2014; Russell, Rodgers, Ukoumunne \& Ford, 2014), although recent reports suggest that these figures are likely to be underestimations. In the UK Millennium Cohort Study, 3.5\% of 11 year-olds were reported to have autism (Dillenburger, Jordan, McKerr \& Keenan, 2014), while between and 2.7\%-3.1\% of children and young people self-declared as having autism in Northern Ireland (Dillenburger, McKerr \& Jordan, 2017). Boys are five times more likely to be on the spectrum than girls (CDC, 2015; Russell, Rodgers, Ukoumunne \& Ford, 2014).

In Mainland China estimates of autism prevalence remain low. For example, Tao (1987) reported that 'the rarity of infantile autism in China is a fact' in 1982 (p. 296). The first epidemiological study of autism in China was reported by Wong and Hui (2007), who estimated a prevalence of $0.0549 \%$ between 1986 and 2005, with $0.161 \%$ of children aged below 15 years of age affected in Hong Kong. Sun et al. (2013) estimated the 
prevalence of autism to be $0.118 \%$ in mainland China and $0.266 \%$ for China, Hong Kong, and Taiwan combined. It is likely that there is a very large undiagnosed population with autism in China because there is little reason to believe that the true prevalence in China is any different to that reported in the UK or internationally (Sun et al., 2013; 2015). The under-diagnosis in China is likely due to the narrow focus on classic autism, rather than the full spectrum, and subsequent delays in diagnosis or misdiagnosis (Sun et al., 2013).

\section{ABA-based Interventions and their Delivery}

$\mathrm{ABA}$ is the application of the science of behaviour analysis to socially relevant behaviours (Baer, Wolf \& Risley, 1968). By as early as 1999, the United States Surgeon General had endorsed a number of ABA-based interventions that are well established for children with autism. ABA-based interventions for autism are typically multi-component and include a number of evidence-based practices, including, but not limited to: Discrete Trial Teaching (DTT; e.g., Lovaas, 1987; Smith, 2001), Incidental Teaching (IT; e.g., Hart \& Risley, 1975), Picture Exchange Communication System (PECS; e.g., Frost \& Bondy, 2002), Pivotal Response Training (PRT; e.g., Koegel \& Koegel, 2006), Verbal Behaviour (Sundberg, 2008), and Early Intensive Behaviour Intervention (EIBI; e.g., Lovaas, 1981, 1987).

There is little comparative research between Western and Chinese intervention practices, despite the fact that most interventions that are used in China have been 'imported' from Western countries (Liu \& Li, 2007; You \& Yang, 2006). Parents have played a central role in developing the limited autism services in China. Over half (56\%) of the founders of agencies delivering autism interventions are parents of children diagnosed with autism, who want to help their own children and those like them (SAS, 2013). In South China, ABA-based interventions are most common (used by $87 \%$ of service providers). Yet, few professionals in China have studied behaviour analysis in depth (Clark \& Zhou, 2005; Huang, Jia \& Wheeler, 2013) and most teachers (91.5\%) feel that they need more training to improve their own skills (SAS, 2013). 
In the UK, professionals usually feel that they are well trained for dealing with autism. However, research suggests that their knowledge-base often does not match their perceptions of competence (Fennell \& Dillenburger, 2016). In fact, there is evidence that autism 'training' often consists of one 2-hour lecture (Dillenburger, McKerr, Jordan, \& Keenan, 2016). Staff training in ABA can be even less advanced (Dillenburger, 2016) despite the fact that there is ample evidence showing that good staff training can enhance competence (McDonnell et al., 2008; Nigro-Bruzzi \& Sturmey, 2010; Spector, Orrell, \& Goyder, 2013).

Clearly, Western practices cannot simply be replicated across cultures (Ney, Lieh-Mak, Cheng \& Collins, 1979). Therefore, the purpose of the present study is to tease out the differences and similarities in the diagnosis process, intervention procedures, and service delivery between the UK and China.

\section{Method}

\section{Participants}

In the UK, professional participants were supervisors $\left(\mathrm{n}=2 ; \mathrm{OE} 1^{1} ; \mathrm{OE} 2\right)$ and therapists ( $\mathrm{n}=3$; OE3; OE4; OE5) (Table 1). A therapist was someone who worked directly with children and a supervisor was someone whose main role was supervising the therapist and who had overall responsibility for managing programmes (Love, Carr, Almason \& Petursdottir, 2009). Professionals (OE1 to OE4) were from a non-profit autism agency in a large city in England(UK). OE5 was a senior practitioner from the Specialist Teaching Team in England. Two parent participants (PE6 \& PE7) were recruited through an online $\mathrm{ABA} / \mathrm{VB}$ community (Table 1), one mother and one father from two different midland cities of England.

${ }^{1}$ OE stands for professionals in the UK and PE stands for parents in the UK;

OC stands for professionals in China and PC stands for parents in China. See Table 1. 
In China, professional participants were founders of agencies $(n=1 ;$ OC5), trainers $(n=1$; OC4), and teachers ( $\mathrm{n}=3$; OC1; OC2; OC 3 ) (Table 2). A number of the professionals were also parents whose children were diagnosed with autism. Therapists in China are frequently called teachers with on-the job training from other more experienced teachers, and in some cases, international behaviour analysts. The 3 teachers (OC1 - OC3) were from Agency A (located in Northern China). OC5 was the founder of Agency S (located in Southern China); she was also included as one of the parent participant (PC4) as her son was diagnosed with autism. OC4 was a special needs education teacher from the USA who had been working in China for over 20 years. She provided special needs training, including the basics of ABA-based methods, for autism agencies and families in China. The 3 parent participants (PC1 - PC3) were recruited from Agency A (Table 2). Of the 3 parents, $\mathrm{PC} 1$ came from Northern China, PC2 came from a Central China, and PC3 came from Southern China.

\section{Setting and recruitment}

The UK sample was recruited in England through an international non-profit company with a number of sites around the world (Agency A). Agency A provided individualised, one-to-one, and group ABA-based programmes in clinic, school and home settings.

The sample in China was recruited through Agency B, located in Northern China. Agency B was a leading NGO (Non-government Organisation) in China and was originally founded by a mother whose child was diagnosed with autism. Agency B had a large autism school that provided on-site services for parents and children, who had temporarily moved to the city for ABA training (usually for one or two months). Most of the ABA-based interventions and training were delivered in a large classroom environment, where parents (mostly mothers) were taught by a teacher, who stood in front of the 'class'. Interviews also took place in Agency S, which was located in Southern China and was also established by a mother, whose child was diagnosed with autism. 


\section{Procedure}

Purposive sampling (Bryman, 2012) was carried out to locate participants mainly through word of mouth in the agencies. While most participants in the UK were interviewed face-to-face, due to practical constraints, telephone interviews were carried out with all other participants. Each interview lasted for approximately one hour and was recorded with participants' permission. In addition, 'QQ chats' (Chinese online chat software) as well as emails were also used to supplement and clarify interview questions.

\section{Research tools}

Semi-structured interviews were created especially for this study, because there were no validated interview schedules that covered the research question adequately (Ritchie \& Spencer, 2002; Silverman, 2006). The interview included demographic information and questions about participants' experiences of ABA-based interventions. The schedule was first developed in English and then translated into Chinese (full copies of the interview schedules are available elsewhere in Liao, 2013).

\section{Data Analysis}

Audio recordings were transcribed by the first author. Chinese interview data were first transcribed in Chinese and then translated into English. Thematic analysis methods were applied to the transcripts, in which information was categorised by codes and then delineated into common themes (Boyatzis, 1998; Braun \& Clarke, 2006). The emerging themes were (1) diagnosis, (2) intervention approach, (3) service delivery, (4) qualification of professionals, and (5) views of ABA. Sub-themes were coded, for example, service delivery was sub-coded into (a) training, (b) role of parents, therapists/teachers, and (c) involvements of professionals.

\section{Research ethics}

Research ethics approval was obtained from the School of Social Work, University of York and the School of Education, Queen's University Belfast. Information and consent forms were sent to each participant. Only participants who signed the informed consent form took part in the interviews. All data were handled according the 
university data protection and storage guidelines. The name of participants and agencies were anonymised.

\section{Results}

\section{Children's Diagnosis and Parental Responses}

In both countries, the diagnosis of the autism was given for behaviours that met the criteria set in the DSM or the ICD. In the UK, relevant professionals, such as nursery teachers were generally the first to raise concerns about the child's developmental progress.

Nursery teachers noticed his behaviour was different and suggested us to take him for an assessment. We were told to fill in some forms and followed his advice to look for tutors to intervene as early as we could. (PE 7)

In China, the first symptoms were generally picked up by the parents. In both countries, parents first reactions to the diagnosis of autism were shock and despair. As a result, family support was of great importance after diagnosis. Mothers were generally the person responsible for taking care of children with autism. In China, gender stereotypes are deeply rooted in society where the father makes money and the mother stays at home to look after children. This is clearest in the case of PC 1 where there was family disagreement.

His father said: 'The local autism agency is quite good [for child's intervention]. Why do you go that far?' He does not believe that our son could be better off going to Beijing for help...... he thinks he will be the same as the other typical kids when the child grows up. I telephoned my son's Grandmother [who also disagreed taking the grandson for further treatment] and told her: 'I do not care whether you can accept my son or not. I will not abandon him.' (PC 1)

\section{Searching for Interventions}


Professionals from the UK and China highlighted that parents sometimes looked for treatments without checking the evidence for their effectiveness. The Internet was the first place to which most parents turned for help. For example, PC3 stated:

I also heard about sensory integration, floor time, picture exchange communication system and structured analysis. I had tried these methods, for example, picture exchange communication system and structured analysis. I sent my son to participate in lots of rehabilitation agencies.

One of the English supervisors, OE 1, observed that parents looked for therapies before coming to Agency A.

We heard crazy things come up, such as swimming with dolphins. It is not effective... I think autism is kind of mysterious. People do not understand fully where it comes from, and parents are desperate at helping their child, so they heard these things from the internet and they tried them.

Chinese ABA teacher OC 2 also talked about her experience with parents.

Some parents used to send their children to other agencies and used other methods.

In the end, parents get lost, knowing nothing about his or her child.

In addition to trying various behavioural and educational therapies, some parents also tried pharmaceutical or dietary interventions. All professional respondents in UK were against the use of medical treatments and neither did they recommend dietary interventions. One parent had used dietary interventions to control the child's aggression. There was also little enthusiasm for such interventions in our Chinese participants. PC 2, mentioned that she had heard about Brain Electronical Wave, but she said she did not use it because she believed that,

it was just a trick. My daughter is too young and I am worried that it will result in side effects.

She chose to use behavioural interventions instead.

\section{Advice from Professionals}


Professionals from both the UK and China believed that 'the earlier you can start working with the child, the better.' OC 2 observed:

Some [children] are not definitively diagnosed [but are sent here to have the intervention] because their parents feel their children have some symptoms [of autism], and come for training. These parents are in a hurry to begin intervention at about 1 or 2 years old, although most children here undertake intervention at ages ranging from $3-7$ years.

English children in the study began interventions later.

We have quite a range of ages here. We find more success with the younger age, predominately around $2-6$, but (there is) one still with us now aged 10 or 11 . We have a student with our service older than that... maybe 8 to 13 , of course, [they are more about learning to] gain social skills. But yeah, I think the most successful case we have is at preschool age (OE2).

\section{Mode of Service Delivery}

ABA-based interventions are widely used for individuals with autism in the USA and Canada, but they are much less widely available in the UK and China (Keenan et al., 2014). Agencies in the UK and China who participated in this study welcomed parental involvement in ABA training. However, there was a major difference in service delivery between the two countries. Chinese autism agencies undertook parent-focused training, whereas in the UK, parents cooperated, while staff conducted the work with the child.

In the UK, professionals, such as ABA therapists, carried out most of the interventions on a one-to-one basis at the child's home, clinic, or in the classroom. Parents generally were not present during the intervention, although English parents exercised parental responsibility through discussions with the therapists and supervisors. The curriculum for each child was agreed with the parents, professionals and, sometimes, school teachers. 
During the supervised time, supervisors will introduce what they are going to do and what strategies will be used. Professionals will help parents develop their own strategies (OE 1)

... one of the reasons we see such enthusiasm is that parents are really ... proactive and very good at working with students. I believe that families have taken on board [ABA knowledge] enabling students to have a whole day to make progress [at home as opposed to the limited time at the centre]. (OE 2)

Typically, there were three sessions per week in Agency A's clinic and two sessions per week at home with their parents. A supervisor accompanied the child to pre-school settings in the morning and to the clinic after school. Monthly team meetings were held with all professionals to make sure parents were aware of and agreed with the ongoing intervention strategies with three monthly reviews and annual workshops with invited external experts. The duration of the programme generally depended on the clients' needs and was also determined by availability of funding.

When we are going into the school, we will meet the [school] teachers ... That means they know what we are working on. And we will supervise the case as well. The teacher will also have our email address and phone numbers if they have any questions. We always recommend parents to work with children for some sessions. It is not only to make sure the intervention to be as effective as possible, but also to aid [in] the generalization. (OE 4)

Sometimes, [parents] observe us [to undertake the intervention], and we help them to try to get involved. Parents come to us and say: "This is what we were struggling at home. Could you help me break down [the skill]?" Parents tell us what they want their child to do. We usually try to encourage them [to] keep on learning ABA, but we always keep in touch with parents about what's happening [with the child at home]. (OE 3)

In China, the mode of service delivery was divided into two types. Type 1 was the most common autism service, combining short periods of Discrete Trial Training, with other therapies, such as structured analysis, sensory integration, 'floor time' and music therapy. 
It was claimed that these therapies were carried out using the principles of $\mathrm{ABA}$, although it was not possible to verify this assertion. Type 2 service delivery offered parent-focused ABA training, like Agency B or parents-assisted group training (professionals delivered one to one training and parents assisted in the group training for social communication skills).

Agency B had two divisions: (1) The Pre-school Division (PD) for children aged around 3-6 years old, which offered intervention courses that lasted for 11 weeks where teachers taught the parents theories and practical skills. At the end of each week, parents were examined to check whether they had mastered these skills and knowledge. Meanwhile, parents took part in workshops and extra-curricular activities. (2) The Group Home that was specifically designed for 12-16 years old students and was akin to a day-care facility. The Treatment and Education of Autistic and Related Communication Handicapped Children approach (TEACCH, Schopler \& Reichler, 1971) also was used in Agency B.

All Agency B staff endorsed service delivery with a focus on parents as the person responsible for their child/children with autism in the long-term. They felt that if parents could master techniques and skills based on ABA, they would be able to apply language or skills training with their children anytime and anywhere. The professionals also thought that parent-focused ABA training provided parents with a good knowledge base of ABA and autism. The courses usually started by introducing parents to autism diagnostic criteria and implications of autism for daily life. The majority of parents were not residents of Beijing but were from different provinces and were eager to avail a quality intervention, so they rented accommodation near Agency B.

However, there were certain concerns raised by Chinese parents. For example, PC 1 said, "they have monitored the course closely, but are not professional." Maintenance of behaviour change was also viewed as problematic. For example, OC 4, an international trainer in Agency B expressed her concern that 'it was hard for parents to maintain [the behaviour change] after the short course.' 


\section{Shortage of Qualified ABA Professionals}

The Behaviour Analyst Certification Board's (BACB, 2016a) standards of training for ABA-based intervention are endorsed internationally and include Registered Behaviour Technician (RBT ${ }^{\mathrm{TM}}$ ), Board Certified assistant Behaviour Analyst (BCaBA), Board Certified Behaviour Analyst (BCBA), and Board Certified Behaviour Analyst-Doctoral (BCBA-D). In the UK, the participating professionals, except OE 1, did not hold any of these qualifications; at best, some were undergoing training with the aim of becoming BCBAs (e.g., OE 2). There are presently 19 BCBA-Ds and a total of 212 BCBAs and BCaBAs and 24 RBTs in the UK (BACB, 2016b).

In China, approved qualifications were also scarce, although those who had been working in the school for many years took the responsibility of supervising and training 'therapists' supported by international trainers/training. OC 4 came from the US and had been training teachers for a number of years. OC 5 went abroad frequently to visit autism programmes and undertook ABA training. In addition, NGO, Non-profit Organisations (NPO) or organisers held training sessions for teachers. None of the participating professionals held BACB approved qualifications. There were 5 BCBAs and $12 \mathrm{BCaBAs}$ in all of mainland China and 40 BCBAs/BCaBAs in Hong Kong (BACB, 2016b); 9 RBTs in mainland China and 9 RBTs in Hong Kong (BACB, 2016b).

Overall, both China and the UK faced the same problem of a shortage of qualified ABA therapists/supervisors. In general, therapists as well as supervisors failed to meet the BACB's requirements, although the number of autism agencies has been growing (McCabe, 2013).

Lack of services in China led to mothers of children with autism starting their own services, as was the case in Agency B and Agency S. This practice continues. Participating Chinese parents stated that when the 11-week long course finished, they planned to start an autism agency in their hometown as their own child would still need the service and other children with autism also need the right training. 
It is not good to stay outside [out of home] for a long time for to learn [ABA and to access intervention services], because I also worry about my elder son's study. We [mothers who are the same hometown with PC1] plan to rent someplace so that children will have a space to play and study [and open to other families with children diagnosed with autism]. I do not care about profits, but just in case some parents err from the right path and delay their child's best time of intervention. However, I am also worried about [set-up] funding and professionals' resources (PC 1).

\section{Critical Voices}

In a sample confined to ABA professionals, English respondents made critical comments. These reflected an emphasis on family nurturing, rather than parent training. For example, OE 5 who had been working with children with disability for over 30 years and with children with autism for 15 years stated:

I am not an advocate of behavioural approaches, such as ABA, for children with autism. Children [diagnosed with autism] may find it difficult to transfer their learning in less structured settings. There is not enough evidence to show that ABA is an effective educational approach despite positive rates of parental satisfaction.

I do not believe in 'modifying' the child. Behaviour modification is a popular approach in the past, when I [was] first qualified as a special needs teacher in the 1980 's, but I feel it is not useful for children with autism as their development are different from typical children.

I think behavioural approaches could lack understanding of the individual needs of the child and not recognize fully how autism is a part of then, which we need to understand. It places too much emphasis on 'changing' the child and is not very empathetic to the child.

Others expressed a more knowledge-based approach: 
It is one of the only treatment interventions used with students with autism. It's actually grounded in scientific research, and has got some proven statistics [sic]. (OE 2)

I do see ABA with family is a benchmark. They [children] would do more things with their family. They picked up more self-help skills; they became more independent...there were a lot of engagement (OE 3$)$.

OE 3 went on to express her individualised view:

...the spectrum is so wide, [and ABA is] individualized. [The] hours depend on their needs, they may need one-to-one. For example, the high spectrum need social [training] in school [and] may need more home session and school intervention. If they are in preschool [like 3-4 years old], they are more one-on-one at home and office. As they are going to school, we have to think about 50\% in school and 50\% in office. If they are 10-16, I would prefer to leave them there. We want them to be more independent. If they need support, we will have the time-table for them.

Chinese respondents tended to express satisfaction with ABA and some like OC 2 made the case for its flexibility:

ABA is a lifelong training method. You can use it anytime and anywhere.

\section{Lack of Financial Support}

Both parents with children diagnosed with autism in the UK and China faced funding problems. In England, the NHS lists approved ABA-based interventions, but does not cover ABA-based intervention costs for children diagnosed with autism. Some financial support is available from Local Authorities for children with special education needs statements, but most parents have to pay for these services themselves. NGOs and charities may provide some assistance on application from parents.

OE 2 said: 
It is not a part of the NHS system right now. It is governed by the local authority $\ldots$, so we can have students from [different local authorities] ... they will gain a certain [limited] amount of money [from their statement].

Parents cannot [avail of service] for longer, like for 4-6 years, because [they] cannot afford it or cannot get funding. Some of them only get 6 month, so the situation [of children with autism] will change. In the best thing, if they can afford it, early intervention will last till 6 or 8 years old (OE 3 ).

In China, parents of young children with autism can apply for funding support from the government, yet commonly this was not enough to cover the cost of the intervention. Usually the funding does not go to the parent but instead, parents are directed to local approved autism agencies for treatment (PC 1, PC3).

The state pension has been distributed to the local agency. If you want reimbursement, you will have to go there (PC 1).

However, OC 1 (from North China) received the same funding as OC 5 (from South China), but cities have different funding systems, Some places have reimbursement and some do not (OC 1).

The NGO is self-financing. The authority does not fund the agency, but will partly support some children diagnosed with autism. For example, children who are under 6-year-old, their family will receive $¥ 12,000$ [around $£ 1,400$ ] per year, and those who are between 7 to 14 years old will receive $¥ 5,000$ [around $£ 590$ ] (OC 5).

\section{Discussion}

The research reported here compared parents' and professionals' experience of ABAbased intervention in the UK and China, focusing on access to diagnosis services, the search for and their experiences of interventions. Findings suggest that the experience and application of ABA are influenced by cultural differences. Results confirm an earlier 
study of over 1000 UK parents that found that 'post-diagnosis, the support (if any) that was provided to parents was limited and unsatisfactory (Crane, Chester, Goddard, Henry \& Hill, 2016, p.153).

Clearly, early diagnosis and intervention make a big difference in the life of children with autism (Fein et al., 2013). Findings reported here showed that there is a need for more well-qualified diagnostic services for autism, both in the UK and in China. Although children can be diagnosed with autism much earlier than previously thought (Herlihy, Knoch, Vibert \& Fein, 2013; Werner, Dawson, Munson \& Osterling, 2005), the age of diagnosis in both countries remains relatively late. These findings confirmed Keenan, Dillenburger, Doherty, Byrne and Gallagher (2010) who reported data suggesting that in the UK, the average age when children were diagnosed was 44 months (nearly 4 years old) and there was an average of 24-30 months between the diagnosis and the first reported concerns regarding the child. In China, Yu (2011) showed only 15\% of parents first raised concern before children were 2 years old, with most raising first concerns after the children were 3 or older. Yu (2011) also indicated that only 4\% of Chinese children received their diagnosis before the age of 2 and $65 \%$ of the children were older than 3 before they were diagnosed.

Mounting evidence that symptoms can be reduced by appropriate behaviour analytic interventions from as early as 6 months-of-age (Rogers, Vismara, Wagner, McCormick, Young \& Ozonoff, 2014) makes early diagnosis not only an ethical and practical imperative, but also economically important (Dillenburger, 2014). Parents and professionals in both the UK and China learnt about ABA-based interventions from the USA, but adapted the practices and service delivery to cultural norms and environments. In China, familial culture and individual values are largely influenced by Kung Chiu or Confucius (551-479 BC) (Hartig, 2012; Hofstede \& Bond, 1988), in which the failure of a child's development through education is largely regarded as a failure of the family (Huang \& Gove, 2012). In addition, family hierarchy is embedded in the Chinese family system (Lim \& Lim, 2004; Wang, 2011), and the role of mother and father were clearly defined and immutable (Chia, Allred \& Jerzak, 1997). That is one of the reasons that 
parent-focused ABA training prevails in China, and mothers are the main family member to travel with their child, from their hometown to big cities to access ABA-based programmes. Local services are often insufficient.

In the UK, early industrialisation and urbanisation (late 18th and early 19th centuries), disrupted family patterns and began a long-term shift to the nuclear family and a lesser role in the upbringing of children for the extended family (Sharma \& Manikutty, 2005). The increase in labour market participation by mothers since the mid twentieth century has led to the increased use of professionalized children's services. Thus, it was not surprising that most UK families relied on professionals to carry out therapy with their child.

In China, the parent-focused mode of service delivery required both parents and children to come together for training in ABA. This is because professionals believed that welltrained parents could adjust ABA-based intervention closely to their daily lives. Intense parental involvement also provided a platform for emotional support (Boyd, 2002). On the other hand, 'one size does not fit all' (Dillenburger, et al., 2014) and providing generalised training to parents does not necessarily translate to individually tailored interventions. Thus, some Chinese autism organisations also carried out professional led one-to-one ABA-based programmes, like in the UK.

Furthermore, the increasing numbers of children diagnosed with autism call for more financial support and an investment of resources from authorities. Families with children diagnosed with autism face greater financial problems, unemployment, and care commitments than other families (Kogan, Strickland, Blumberg, Singh, Perrin \& van Dyck, 2008). The mean cost for a family seeking services for young children with autism (aged 24-60 months) was $£ 430$ per month (ranged from $£ 53$ to $£ 1,116$ ) in the UK (Barrett et al., 2012). A systematic review of the costs of autism in the UK and the USA (Buescher, Cidav, Knapp \& Mandell, 2014) estimated an individual lifetime cost of £0.91.5 million (US\$2.2 million) depending of level of support needs. Well designed, early ABA-based interventions can significantly reduce this cost with savings up to £1million 
per life-time ( Chasson, Harris \& Neely, 2007; Motiwala, Gupta, Lilly, Ungar \& Coyte, 2006; Penner et al., 2015; Peters-Scheffer, Didden, Korzilius \& Matson, 2012).

In China, children diagnosed with autism were first included in the Second China National Sample Survey on People with Disability in 2006 and autism was categorised as psychiatric disorder (State Statistics Bureau, 2007). In June 2006, the 'Rehabilitation Services for All' were indicated as one of the key targets in the Outline of the Persons with Disabilities during the Guidance of 11th Five-year Development Programme Period (2006-2010) $)^{2}$, in which a nationwide training for people with autism was formally stated (CDPF, 2008). A total of 31 cities were selected as pilot locations to implement policies, i.e., promoting the maternal and children health care, establishing special needs education network and arranging social resources to help people with autism (The People's Daily Overseas Edition, 2009) and in 2014, 41 provincial-level rehabilitation training centres were built up (CDPF, 2015). An annual amount of $¥ 12,000$ (around $£ 1,400$ ) was provided for each child diagnosed with autism to attend approved autism organisations (CPG, 2011). This amount is only available to children between 3- to 6-year-old who are from families of low socio-economic status. However, the policy supporting system favours young children (Wang, 2015) and different regions have different implementation performance. In addition, people with disability are issued with a Disability Certificate from the authority for public services and funding support. The process of applying for the certificate is time-consuming ( $\mathrm{Du}, 2011$ ), which delays the uptake of early intervention. Moreover, some parents were not willing to apply for this certificate because of the concern about labelling (Sun, Allison, Auyeung, Matthews, Baron-Cohen, \& Brayne, 2013). However, findings reported here show that parents from rural China often used this funding to avail of autism specific parent training in the cities.

Professional respondents in the UK reported that the extent to which children availed of ABA-based programmes depended largely on the extent of funding available. While the

\footnotetext{
${ }^{2}$ The Guidance of the Five-year Development Programme is a series of social and economic guidance which was initiated by the Central government of P.R.C. every five years (Wikipedia, n.d.)
} 
NHS included ABA-based interventions in their publicity materials, these are largely funded through the education system, which is not available for younger children. In fact, statutory bodies frequently referred parents who wanted to access ABA-based interventions to the voluntary sector (DENI, 2002). Though some of these voluntary organisations had expertise in ABA, there is a need for a structured process to enable the transition from the intervention services to the school system (Belling et al., 2014).

Both China and UK shared the same problem in the high cost of family investments in terms of time and money, limited resources and a huge demand for interventions. There is a need for the authorities to listen to the experience of parents and service providers and to include more evidence-based ABA-based interventions to benefit a large group of children with autism.

Finally, to further maximise the utilisation of the network of behaviour analysis, it is vital to explore an international collaboration among qualified professionals. This is especially important for those countries whose first language is not English, like China or European countries for which it is hard to understand the research and practice of behaviour analysis directly without the help of an interpreter or translator (Keenan, Dillenburger, Moderato \& Röttgers, 2010). Having said this, some Chinese organisations invited overseas experts to China (e.g., China Soong Ching Ling Foundation, 2015) or sent teachers abroad for ABA training. Mainly due to its unprecedented success in supporting populations affected by autism, there now is a huge demand for behaviour analysts around world, e.g., an increase of 118\% of BCBA was recorded from 2002 to 2014 (BACB, 2015).

\section{Limitations}

The present study had several limitations. First, a relatively small number of participants were involved in this study. Therefore, the opinions expressed here cannot be interpreted as representative. In addition, the present study was based on a local purposive sampling in the UK and China, thus, the responses may not be generalised to other regions of each country or to other countries. Furthermore, no data on treatment fidelity or behavioural 
outcomes were reported. However, the aim of this study was not to offer a comprehensive overview, it was merely using international perspective to illustrate cultural differences in the use of ABA-based intervention programmes in each country. Further research is underway to make available more generalizable data sets.

\section{Conclusions}

Participating parents of children with autism favoured ABA-based interventions for their children. Culture and policy environment play a substantial role in the effectiveness of service delivery of ABA-based intervention.

Culture dictates the method of service delivery. In China, parents (mostly mothers) had greater involvement in the treatment, attending ABA training sessions with their children having temporarily moved away from home to a large town school setting. Subsequently, they worked with their own child under the supervision of a skilled professional, in the way that was similar to therapists in the UK. There are some key advantages to this approach, including skills maintenance, generalisability, and social support amongst parents.

In contrast, the parents in the English system were more reliant on professional input. Professionals used ABA-based intervention work in conjunction with the education system while the parents adopted a family nurturing, rather than a parent-training role. The advantage in the English system was the individualisation of the programmes for each child and the cooperation between school, clinic, and the home. The control exercised by professionals is also likely to result in increased intervention fidelity.

The cultural differences and policy environments prescribe the delivery of service. In China, there is likely to be a continuous growth in demand as autism diagnosis improves and the age of diagnosis reduces. It is possible that there will be a concurrent change in patterns of family organisation in China as more women enter the work force and the adoption of two-child policy on 1 Jan 2016 (Xinhua net, 2015). This will have implications for the sustainability of the parent-focused approach to ABA over and above 
the need to change the system to reflect the needs of individual children. As a result, the current policies will need to adapt to these changing needs. A more flexible approach is required to manage the transition towards more professional and evidence-based treatments as well as moving the responsibility away from the parents. In the English system, the challenges include resistance to behaviour analytic interventions within some powerful lobbies which are impeding the rollout of evidence-based treatments. As a result, parents need to be proactive in engaging these services if they want their child to receive ABA-based interventions (ABA4ALL, 2014).

In conclusion, this study showed that while the science of behaviour analysis is the same internationally, its applications vary widely across cultural contexts. Behaviour analysts should be aware of cultural differences when they work with families from different ethnic backgrounds and remain open and flexible to adjusting their practices accordingly.

\section{Acknowledgement}

Data reported here stem from research conducted in part-fulfilment of the Master by Research (MRes) in Social Work by the first author at University of York under the supervision of the third author (Liao, 2013).

\section{Funding}

The first author was funded by Queen's University Belfast/China Scholarship Council $\mathrm{PhD}$ studentship under the supervision of the second author.

\section{References}

ABA4ALL. (2014). Community of parents of children with autism. Retrieved from www.facebook.com/ABAforallchildren/info

American Psychiatric Association. (APA, 1980). Diagnostic and Statistical Manual of Mental Disorders (3rd ed.). Washington, DC: Author. 
American Psychiatric Association. (APA, 2013). Diagnostic and Statistical Manual of Mental Disorders (5th ed.). Washington, DC: Author.

Baer, D. M., Wolf, M. M. \& Risley, T. R. (1968). Some current dimensions of applied behavior analysis. Journal of Applied Behaviour Analysis, 1(1), 91-97. doi: 10.1901/jaba.1968.1-91

Barrett, B., Byford, S., Sharac, J., Hudry, K., Leadbitter, K., Temple, K., Aldred, C., Slonims, V. \& Green, J. (2012). Service and wider societal costs of very young children with autism in the UK. Journal of Autism and Developmental Disorders, 42(5), 797-804. doi: 10.1007/s10803-011-1306-x

Behaviour Analyst Certification Board. (BACB; 2015). October 2015 Newsletter. US Behaviour Analyst Workforce: Understanding the national demand for behaviour analysts. Retrieved from http://bacb.com/wp-content/uploads/2015/10/151009burning-glass-report.pdf

Behaviour Analyst Certification Board (BACB, 2016a). About BACB. Retrieved from: http://www.bacb.com/index.php?page=4

Behaviour Analyst Certification Board. (BACB, 2016b). Find/Contact Certificants. Retrieved from http://www.bacb.com/index.php?page=100155

Belling, R., McLaren, S., Paul, M., Ford, T., Kramer, T., Weaver, T., Hovish, K., Islam, Z., White, S. \& Singh, S.P. (2014). The effect of organisational resources and eligibility issues on transition from child and adolescent to adult mental health services. Journal of Health Services Research and Policy, 19 (3), 169-176. DOI:10.1177/1355819614527439

Boyatzis, R. (1998). Qualitative Information: Thematic Analysis and Code Development, Thousand Oaks, CA: Sage Publication 
Boyd, B. A. (2002). Examining the relationship between stress and lack of social support in mothers of children with autism. Focus on Autism and Other Developmental Disabilities, 17(4), 208-215.

Braun, V., \& Clarke, V. (2006). Using thematic analysis in psychology. Qualitative research in psychology, 3(2), 77-101. Doi:10.1177/10883576020170040301

Bryman A. (2012) Social Research Methods. (4th ed.) Oxford: Oxford University Press.

Buescher, A. V., Cidav, Z., Knapp, M. \& Mandell, D. S. (2014). Costs of autism spectrum disorders in the United Kingdom and the United States. Journal of the American Medical Association Pediatrics, 168(8), 721-728.

doi:10.1001/jamapediatrics.2014.210

Central People's Government of the People's Republic of China (CPG, 2011). 'Colourful Dream Action Plan' Implementation Scheme on Helping Children with Disability. [ 残疾儿童康复救助“七彩梦行动计划”实施方案]. Retrieved from http://www.gov.cn/fwxx/cjr/content_2440510.htm

Centre for Disease Control and Prevention. (CDC, 2015). Data \& Statistics. Retrieved from http://www.cdc.gov/ncbddd/autism/data.html

Chasson, G. S., Harris, G. E. \& Neely, W. J. (2007). Cost comparison of Early Intensive Behavioral Intervention and special education for children with autism. Journal of Child and Family Studies, 16(3), 401-413. Doi:10.1007/s10826-006-9094-1

Chia, R. C., Allred, L. J. \& Jerzak, P. A. (1997). Attitudes toward women in Taiwan and China. Psychology of Women Quarterly, 21(1), 137-150. Doi: 10.1111/j.14716402.1997.tb00105.x 
China Disabled Persons' Federation (CDPF, 2008). The Outline of the Work for Persons with Disabilities during the 11th Five-year Development Program Period. Retrieved from

http://www.cdpf.org.cn/english/laws1documents/200804/t20080410_267463.html

China Disabled Persons' Federation (CDPF, 2015). The 2014 Chinese Statistical Bulletin of Development Programme for People with Disability [2014 年中国残疾人事业发 展统计公报 残联发（2015）. Retrieved from http://www.cdpf.org.cn/zcwj/zxwj/201503/t20150331_444108.shtml

China Soong Ching Ling Foundation. (2015). The $1^{\text {st }}$ International conference on autism therapy and rehabilitation held in Beijing. Retrieved from http://sclf.cri.cn/261/2015/10/08/2s8641.htm

Clark, E. \& Zhou, Z. (2005). Autism in China: From acupuncture to applied behaviour analysis. Psychology in the Schools, 42(3), 285-295. Doi: 10.1002/pits.20079

Crane, L., Chester, J. W., Goddard, L., Henry, L. A., \& Hill, E. (2016). Experiences of autism diagnosis: A survey of over 1000 parents in the United Kingdom. Autism, 20(2):153-62. doi:10.1177/1362361315573636

Department of Education Northern Ireland. (DENI, 2002). Report of the Task Group on Autism. Department of Education Northern Ireland. Special Education Branch. Retrieved from https://tinyurl.com/yae8da5j

Department of Health, Social Services and Public Safety. (DHSSPS, 2014). The Prevalence of Autism (including Asperger's Syndrome) in School age Children in Northern Ireland 2014. Retrieved from http://www.dhsspsni.gov.uk/index/statistics/asd-children-ni-2014.pdf 
Dillenburger, K. (2014). Why early diagnosis of autism in children is a good thing. The Conversation. Retrieved from http://tinyurl.com/p2zcwqi

Dillenburger, K. (2016). Staff Training. In J.L. Matson (ed.) Handbook of Treatments for Autism Spectrum Disorder. Autism and Child Psychopathology Series, Springer International Publishing AG Doi:10.1007/978-3-319-61738-1_7

Dillenburger, K., Jordan, J. A., McKerr, L. \& Keenan, M. (2014). The Millennium child with autism: Early childhood trajectories for health, education and economic wellbeing. Developmental Neurorehabilitation, 18(1), 37-46. doi:10.3109/17518423.2014.964378

Dillenburger, K., McKerr, L., Jordan, J.-A., \& Keenan, M. (2016). Staff training in autism: The one-eyed wo/man.... International Journal of Environmental Research and Public Health, 13. 13(7). pii-E716. doi: 10.3390/ijerph13070716

Dillenburger, K., Röttgers, H. R., Dounavi, K., Sparkman, C., Keenan, M., Thyer, B. \& Nikopoulos, C. (2014). Multidisciplinary teamwork in autism: Can one size fit all? The Australian Educational and Developmental Psychologist, 31(02), 97-112. Doi:10.1017/edp.2014.13

Dillenburger, K., J. -A. Jordan, L. McKerr, K. Lloyd, and D. Schubotz. (2017). Autism awareness in children and young people: Surveys of two populations. Journal of Intellectual Disability Research 61(8), 766-777. Doi:10.1111/jir.12389.

Du Y. (2011). The research on autistic children caregivers' social support network: Taking 10 caregivers in Jiangsu and Zhejiang province for example. [自闭症儿童照 顾者的社会支持网络研究: 以江浙地区 10 个自闭症儿童照顾着为例]. (Unpublished Master's thesis). China Youth University for Politics Sciences, Beijing, China. 
Fein, D., Barton, M., Eigsti, I. M., Kelley, E., Naigles, L., Schultz, R. T., Stevens, M., Helt, M., Orinstein, A., Rosenthal, M., Troyb, E. \& Tyson, K. (2013). Optimal outcome in individuals with a history of autism. Journal of Child Psychology and Psychiatry, 54(2), 195-205. Doi:10.1111/jcpp.12037

Fennell, B., \& Dillenburger, K. (2016). Applied behaviour analysis: What do teachers of students with autism spectrum disorder know. International Journal of Educational Research. 54(2), 195-205. http://doi.org/10.1111/jcpp.12037

Frith, U. (Ed.). (1991). Autism and Asperger Syndrome. Cambridge, UK: Cambridge University Press.

Frost, L., \& Bondy, A. (2002). The Picture Exchange Communication System Training Manual. Pyramid Educational Products, Incorporated. ISBN: 9781928598053

Hart, B., \& Risley, T. R. (1975). Incidental teaching of language in the preschool. Journal of Applied Behaviour Analysis, 8(4), 411-420. doi:10.1901/jaba.1975.8-411

Hartig F. (2012). Confucius Institutes and the rise of China. Journal of Chinese Political Science, 17(1), 53-76. Doi:10.1007/s11366-011-9178-7

Herlihy, L., Knoch, K., Vibert, B. \& Fein, D. (2013). Parents' first concerns about toddlers with autism spectrum disorder: Effect of sibling status. Autism, 0(0), 1-9. Doi: $10.1177 / 1362361313509731$

Hofstede, G. \& Bond, M. H. (1988). The Confucius connection: From cultural roots to economic growth. Organizational Dynamics, 16(4), 5-21. Doi:10.1016/00902616(88)90009-5 
Huang, A. X., Jia, M. \& Wheeler, J. J. (2013). Children with autism in the People's Republic of China: diagnosis, legal issues, and educational services. Journal of Autism and Developmental Disorders, 43(9), 1991-2001. Doi:10.1007/s10803-012$1722-6$

Huang, G. H. \& Gove M. (2012). Confucianism and Chinese families: Values and practices in education. International Journal of Humanities and Social Science, 2 (3), 10-14. Doi:10.1007/978-3-319-16390-1 3

Kanner, L. (1943). Autistic disturbances of affective contact. Nervous Child, 2(3), $217-$ 250. PMID:4880460

Keenan, M., Dillenburger, K., Doherty, A., Byrne, T. \& Gallagher, S. (2010). The experiences of parents during diagnosis and forward planning for children with autism spectrum disorder. Journal of Applied Research in Intellectual Disabilities, 23(4), 390-397. Doi:10.1111/j.1468-3148.2010.00555.x

Keenan, M., Dillenburger, K., Moderato, P. \& Röttgers, H. R. (2010). Science for sale: But at what price? ABA and treatment of autism in Europe. Behaviour and Social Issues, 19, 126-143.

Keenan, M., Dillenburger, K., Röttgers, H.-R., Dounavi, K., Jónsdóttir, S. L., Moderato, P., Schenk, J.A.M., Virués-Ortega, J., \& Roll-Pettersson, L. (2014). Autism and ABA: The gulf between North America and Europe. Review Journal of Autism and Developmental Disorders. 2(2), 167-183. Doi:10.1007/s40489-014-0045-2

Koegel, R. L., \& Kern Koegel, L. (2006). Pivotal Response Treatments for Autism: Communication, Social, and Academic Development. Baltimore, MD: Brookes.

Kogan, M. D., Strickland, B. B., Blumberg, S. J., Singh, G. K., Perrin, J. M. \& van Dyck, P. C. (2008). A national profile of the health care experiences and family impact of 
autism spectrum disorder among children in the United States, 2005-2006.

Pediatrics, 122(6), e1149-e1158. Doi:10.1542/peds.2008-1057.

Liao, Y. (2013). Applied behaviour analysis for children diagnosed with autism spectrum disorder: A comparative study between England and China. (Unpublished Master's thesis). University of York, York, UK.

Lim, S. L. \& Lim, B. K. (2004). Parenting style and child outcomes in Chinese and immigrant Chinese families-current findings and cross-cultural considerations in conceptualization and research. Marriage \& Family Review, 35(3-4), 21-43. doi.org/10.1300/J002v35n03_03

Liu, H. \& Li, Y. (2007). Application of applied behaviour analysis in rehabilitation training for children with autism. [应用行为分析在自闭症儿童康复训练中的应用]. Chinese Journal of Special Education, 3 (81), 33-37. Doi:10.3969/j.issn.10073728.2007.03.007

Lovaas, O. I. (1981). Teaching Developmentally Disabled Children: The Me Book. Baltimore, MD: University Park Press.

Lovaas, O.I. (1987). Behavioural treatment and normal educational and intellectual functioning in young autistic children. Journal of Consulting and Clinical Psychology, 55(1), 3-9. 0022-OO6X/87/\$OO 75

Love, J. R., Carr, J. E., Almason, S. M. \& Petursdottir, A. I. (2009). Early and intensive behavioural intervention for autism: A survey of clinical practices. Research in Autism Spectrum Disorders, 3(2), 421-428. Doi:10.1016/j.rasd.2008.08.008

McCabe, H. (2013). Bamboo shoots after the rain: Development and challenges of autism intervention in China. Autism, 17(5), 510-526. Doi:10.1177/1362361312436849 
McDonnell, A., Sturmey, P., Oliver, C., Cunningham, J., Hayes, S., Galvin, M., Walshe, C., \& Cunningham, C. (2008). The effects of staff training on staff confidence and challenging behavior in services for people with autism spectrum disorders. Research in Autism Spectrum Disorders, 2(2), 311-319. Doi:10.1016/j.rasd.2007.08.001

Motiwala, S. S., Gupta, S., Lilly, M. B., Ungar, W. J., \& Coyte, P. C. (2006). The costeffectiveness of expanding intensive behavioural intervention to all autistic children in Ontario. Healthcare Policy, 1(2), 135-51. PMCID:PMC2585334

Ney, P., Lieh-Mak, F., Cheng, R. \& Collins, W. (1979). Chinese autistic children. Social Psychiatry, 14(3), 147-150. Doi:10.1007/BF00582181

Nigro-Bruzzi, D., \& Sturmey, P. (2010). The effects of behavioral skills training on mand training by staff and unprompted vocal mands by children. Journal of Applied Behavior Analysis, 43(4), 757-61. Doi:10.1901/jaba.2010.43-757

Penner, M., Rayar, M., Bashir, N., Roberts, S. W., Hancock-Howard, R. L. \& Coyte, P. C. (2015). Cost-effectiveness analysis comparing pre-diagnosis Autism Spectrum Disorder (ASD)-targeted intervention with Ontario's Autism Intervention Program. Journal of Autism and Developmental Disorders, 45(9):2833-47, Doi:10.1007/s10803-015-2447-0

Peters-Scheffer, N., Didden, R., Korzilius, H. \& Matson, J. (2012). Cost comparison of early intensive behavioural intervention and treatment as usual for children with autism spectrum disorder in The Netherlands. Research in Developmental Disabilities, 33(6), 1763-72. EJ988600

Ritchie, J. \& Spencer, L. (2002). Qualitative data analysis for applied policy research, p305-329. In Huberman, M. \& Miles, M. B. (2002). The qualitative researcher's companion. London: Sage publication. 
Rogers, S. J., Vismara, L., Wagner, A. L., McCormick, C., Young, G. \& Ozonoff, S. (2014). Autism treatment in the first year of life: A pilot study of infant start, a parent-implemented intervention for symptomatic infants. Journal of Autism and Developmental Disorders, 44(12):2981-2995. Doi:10.1007/s10803-014-2202-y

Russell, G., Rodgers, L. R., Ukoumunne, O. C. \& Ford, T. (2014). Prevalence of parentreported ASD and ADHD in the UK: Findings from the Millennium Cohort Study. Journal of Autism and Developmental Disorders, 44(1), 31-40.

Doi:10.1007/s10803-013-1849-0

Schopler, E. and Reichler, R. (1971). Parents as co-therapists in the treatment of psychotic children. Journal of Autism and Childhood Schizophrenia, 1 (1), 87-102. PMID:5172443

Sharma, P. \& Manikutty, S. (2005). Strategic divestments in family firms: Role of family structure and community culture. Entrepreneurship Theory and Practice, 29(3), 293311. Doi:10.1111/j.1540-6520.2005.00084.x

Shenzhen Autism Society. (SAS; 2013) Autistic People Survey in Southern China. Beijing: Huaxia Publication.

Silverman D. (2006) Interpreting Qualitative Data: Methods for Analyzing Talk, Text and Interaction. ( $3^{\text {rd }}$ ed). London: Sage publication.

Smith, T. (2001). Discrete trial training in the treatment of autism. Focus on Autism and other Developmental Disabilities, 16(2), 86-92. Doi:10.1177/108835760101600204

Spector, A., Orrell, M., \& Goyder, J. (2013). A systematic review of staff training interventions to reduce the behavioural and psychological symptoms of dementia. Ageing Research Reviews, 12(1), 354-364. Doi:10.1016/j.arr.2012.06.005 
State Statistics Bureau. (2007). Main Statistic Report of the Second China National Sample Survey on Disability. [第二次全国残疾人抽样调查主要数据公报]. Retrieved from http://www.stats.gov.cn/tjsj/ndsj/shehui/2006/html/fu3.htm

Sundberg, M. L. (2008). Verbal Behaviour Milestones Assessment and Placement Program: The VB-MAPP. Concord, CA: AVB Press.

Sun X., Alison C., Mattews F., Sharp S., Auyeung B., Baron-Cohen S., \& Brayne, C. (2013). Prevalence of autism in mainland China, Hong Kong and Taiwan: A systematic review and meta-analysis. Molecular Autism, 4 (7), 1-13. Doi:10.1186/2040-2392-4-7

Sun, X., Allison, C., Matthews, F. E., Zhang, Z., Auyeung, B., Baron-Cohen, S. \& Brayne, C. (2015). Exploring the underdiagnoses and prevalence of autism spectrum conditions in Beijing. Autism Research, 8(3), 250-260. Doi:10.1002/aur.1441

Tao, K. T. (1987). Infantile autism in China. Journal of Autism and Developmental Disorders, 17(2), 289-296. Doi.org/10.1007/BF01495062

The People's Daily Overseas Edition. (2009). Fight against 'Loneliness’ (Autism). [向‘孤 独，宣战]. Retrieved from http://paper.people.com.cn/rmrbhwb/html/200904/14/content_232424.htm

United States Surgeon General. (1999). Mental health: A report of the Surgeon General. Washington, DC: Author.

Wang, J. (2011). Culture differences and English teaching. English Language Teaching, 4 (2), 223-230. Doi:10.5539/elt.v4n2p223 
Wang, Y. (2015). A study on the rehabilitation development of adolescents with disability. [残疾青少年的康复发展状况研究]. China Youth Study, 4, (1), 10-17.

Werner, E., Dawson, G., Munson, J. \& Osterling, J. (2005). Variation in early developmental course in autism and its relation with behavioural outcome at 3-4 years of age. Journal of Autism and Developmental Disorders, 35(3), 337-350. PMID:161 19475

Wikipedia. (n.d.) Five-year plans of China. Retrieved from https://en.wikipedia.org/wiki/Five-year_plans_of_China

Wong, V. C. \& Hui, S. L. (2007). Epidemiological study of autism spectrum disorder in China. Journal of Child Neurology, 23(1):67-72. Doi:10.1177/0883073807308702

Xinhua net. (2015). China to allow two children for all couples. Retrieved from http://news.xinhuanet.com/english/2015-10/29/c_134763507.htm

You, N. \& Yang, G. (2006). A review of studies on autism: Diagnosis and intervention. [自闭症诊断与干预研究综述]. Chinese Journal of Special Education, 7(73), 26-31. R749.94

Yu, J. (2011). The situation of early education on autistic children in Jilin province and the countermeasures. [吉林省孤独症儿童早期教育康复现状及对策]. Journal of Changchun University, 21 (12), 91-94. Doi:10.3969/j.issn.1009-3907.2011.06.027 
Table 1: Participants in England

\begin{tabular}{|c|c|c|c|c|c|}
\hline Category & $\begin{array}{l}\text { Case } \\
\text { No. }\end{array}$ & Position & $\begin{array}{l}\text { Working } \\
\text { years in the } \\
\text { field of } \\
\text { autism }\end{array}$ & $\begin{array}{l}\text { Education } \\
\text { qualification }\end{array}$ & From \\
\hline \multirow{5}{*}{ Professional } & OE 1 & $\begin{array}{l}\text { Director/ } \\
\text { BCBA }\end{array}$ & 15 & $\begin{array}{c}\text { Master in } \\
\text { ABA }\end{array}$ & Agency A \\
\hline & OE 2 & $\begin{array}{c}\text { ABA } \\
\text { supervisor }\end{array}$ & 10 & $\begin{array}{c}\text { BSc / Master } \\
\text { in ABA } \\
\text { undergoing }\end{array}$ & Agency A \\
\hline & OE 3 & $\begin{array}{c}\text { ABA } \\
\text { therapist }\end{array}$ & 8 & $\begin{array}{l}\text { Master } \\
\text { Cognitive } \\
\text { Science }\end{array}$ & Agency A \\
\hline & OE 4 & $\begin{array}{c}\text { ABA } \\
\text { therapist }\end{array}$ & 2 & $\begin{array}{l}\text { Bachelor } \\
\text { Degree }\end{array}$ & Agency A \\
\hline & OE 5 & $\begin{array}{c}\text { Senior } \\
\text { Practitioner }\end{array}$ & 15 & Unknown & $\begin{array}{c}\text { Specialist } \\
\text { Teaching Team }\end{array}$ \\
\hline \multirow[b]{2}{*}{ Parent } & & & & Child gender & Child Age \\
\hline & $\begin{array}{l}\text { PE } 6 \\
\text { PE } 7\end{array}$ & $\begin{array}{l}\text { Mother } \\
\text { Father }\end{array}$ & & $\begin{array}{l}\text { Boy } \\
\text { Boy }\end{array}$ & $\begin{array}{c}20 \\
4\end{array}$ \\
\hline
\end{tabular}


Table 2: Participants in China

\begin{tabular}{|c|c|c|c|c|c|}
\hline Category & $\begin{array}{l}\text { Case } \\
\text { No. }\end{array}$ & Position & $\begin{array}{l}\text { Working years } \\
\text { in the field of } \\
\text { autism }\end{array}$ & $\begin{array}{c}\text { Education } \\
\text { qualification }\end{array}$ & From \\
\hline \multirow{4}{*}{ Professionals } & OC 1 & Teacher & 10 & $\begin{array}{l}\text { Bachelor in } \\
\text { Social Work }\end{array}$ & Agency B \\
\hline & $\mathrm{OC} 2$ & Teacher & 12 & $\begin{array}{c}\text { Junior } \\
\text { College in } \\
\text { Social Work }\end{array}$ & Agency B \\
\hline & OC 3 & Teacher & 12 & $\begin{array}{c}\text { Junior } \\
\text { College in } \\
\text { Social Work }\end{array}$ & Agency B \\
\hline & OC $5 *$ & $\begin{array}{l}\text { Behaviour } \\
\text { therapist } \\
\text { Founder/ } \\
\text { Mother }\end{array}$ & 5 & $\begin{array}{l}\text { PhD in } \\
\text { Special } \\
\text { Education } \\
\text { Bachelor } \\
\text { Degree }\end{array}$ & $\begin{array}{l}\text { International } \\
\text { trainer from the } \\
\text { US } \\
\text { Agency S (the } \\
\text { Founder) }\end{array}$ \\
\hline \multirow[b]{2}{*}{ Parents } & & & Parent Age & Child gender & Child age \\
\hline & $\begin{array}{l}\text { PC } 1 \\
\text { PC } 2 \\
\text { PC } 3 \\
\text { PC 4* }\end{array}$ & $\begin{array}{c}\text { Mother } \\
\text { Mother } \\
\text { Mother } \\
\text { Teacher/M } \\
\text { other }\end{array}$ & $\begin{array}{l}42 \\
36 \\
31 \\
32\end{array}$ & $\begin{array}{l}\text { Boy } \\
\text { Girl } \\
\text { Boy } \\
\text { Boy }\end{array}$ & $\begin{array}{c}41 / 4 \\
4 \\
41 / 2 \\
8\end{array}$ \\
\hline
\end{tabular}

*OC 5 and PC 4 was the same person, with the multiple role of founder, teacher and mother 